\title{
Weaving Textiles:
}

\section{Textile Consumption for Travel and Warfare}

\begin{abstract}
Textile research has demonstrated that new types of textiles were introduced to Scandinavia in the latter part of the Scandinavian Iron Age (AD 700-900). The archaeology of the period displays an increased number of textile tools, and large concentrations of pit houses dedicated to textile production. This era also saw the introduction of sails to Scandinavia, which is one of the obvious reasons for textiles and textile production becoming such an important part of Viking Age society. However, hitherto the value of the textiles has mostly been ignored, and its impact rarely discussed in research. This article will attempt to remedy this and poses important questions, such as: what was the economic value of the textiles needed for travel and warfare, and what was the value of the textiles used on a journey? In the article, the $10^{\text {th }}$ century Ladby ship from Fyn in Denmark, is used to exemplify the demands and economic value of all textiles of one single ship, on one journey. I will use an interdisciplinary approach, including analyses of archaeological textiles; iconography; and early medieval texts. The aim of this novel method is to highlight the importance of textiles. It will also explore how journeys under sail and warfare contributed to the increased consumption of textiles.
\end{abstract}

\section{Introduction}

How much textiles were required for journeys, and what types of clothing were suitable as battle garments? In this article, I will explore these questions through an interdisciplinary approach, including analyses of archaeological textiles, iconography, and early medieval texts. The results are closely related to a more general discussion regarding the importance of textiles and their relevance for social, cultural and political change in Viking Age Scandinavia. In addition, I will explore the famous Danish ship burial at Ladby, on Fyn, which was excavated in 1935, and revealed lavish textile finds from the first half of the $10^{\text {th }}$ century (Sørensen 2001). It will exemplify the amount and economic value of textiles that were required for one single ship. This novel approach will provide important insights and

Contact: Eva Andersson Strand, E-mail: evaandersson@hum.ku.dk

1 Centre for Textile Research, Saxo Institute, University of Copenhagen 
perspectives on the importance of textiles, and initiate a discussion on how the use of sails and their impact on warfare would have contributed to an increased consumption of textiles.

The Scandinavian Viking Age was a period of formidable socio-political expansion, of transition, and change, characterised by overseas trade, warfare, and colonisation. Additionally, textile research has shown that the Viking Age was a period in which the production and consumption of textiles increased and became more specialised. However, textiles are perishable, and there is a dearth of finds, such as complete garments, or sails. This is probably one of several reasons for textiles and their value being left out of discussions regarding the past, in spite of the widespread knowledge that survival without clothing in Scandinavia would be virtually impossible, and that Norse travel to Iceland or Greenland would have been unfeasible without sails. Through my combination of sources I will demonstrate the complexity and value of textiles and textile production. By integrating the results in a general discussion I will demonstrate how they interacted with, and facilitated social, cultural and economic change in Viking Age Scandinavia. It is, however, not possible to cover all these aspects within the context of one article. Instead I will focus on estimating and discussing the textiles that were used on the Ladby ship, and their economic value.

\section{Background}

New and previous textile research

There are several indicators for changes to the textile production of the Late Scandinavian Iron Age (Bender Jørgensen 1986: 355; Andersson 1996; Mannering 2016, 2017). Recent fibre analyses made in the project Fashioning the Viking Age ${ }^{1}$ clearly demonstrate that the wool quality changed radically during the Viking Age, becoming coarser compared to previous periods, indicating either a new type of sheep, changes due to breeding, or new types of wool processing (Skals, Mannering and Andersson Strand et al. forthcoming). These new types of wool, which came from sheep that had long strong hairs and soft under-coats, were excellent for the production of sailcloth but also affected the production of fabrics used for clothes. Archaeologists have previously assumed that flax was the most common textile plant fibre in the Viking Age (see for example Hägg 1984; Bender Jørgensen 1986). However, new pollen analyses indicate that hemp cultivation increased dramatically in Sjælland, Denmark, during the period (Mortensen in prep. and oral communication), and recent fibre analyses of early medieval textiles confirm that hemp was more common than previously thought (Skoglund et al. 2013). It has been suggested that this may be related to the increased demand for sailcloth, and it should be noted that hemp and flax fibres have been commonly used for sailcloth also in historical periods (Andersen and Bischoff 2016: 138).

Analyses of textiles dated to the Late Iron Age reveal that the warp yarn became more hard-spun, the number of threads per centimetre increased, and the fabrics became more warp dense. Compared to earlier parts of the Scandinavian Iron Age (500 BC-AD 500) more tabby-weave textiles were made, furthermore, the amount of plain, well-balanced twills decreased, while twill techniques with more warps than wefts became more common (Bender Jørgensen 1986: 355); also, checked and striped textiles disappeared and the fabrics became monochrome and spin patterned (Mannering 2017: 38). Furthermore, the documentation and analyses of textile tools dated to the Viking Age display an increased number of wool combs, spindles with spindle whorls, and loom weights from warp-weighted 
looms. Large concentrations of pit-houses dedicated to textile production became more and more common, indicating an organised textile production, which exceeded the needs of individual households (Andersson 1996, 2003; Andersson Strand 2016; Gebaur Thomsen 2016; Sarauw 2019).

There is proof that Scandinavian textile production was well established already in the Early Iron Age (Bender Jørgensen 1986; Mannering, Gleba, Bloch Hansen et al. 2012), so what do these changes signify? A couple of reason could be the increased need for sailcloth, and the introduction of new types of clothing and other textile utensils used for travel and war. When sails were introduced in Scandinavia has been debated but they were already present in the iconography of the $6^{\text {th }}$ century (Bender Jørgensen 2012; Andersen and Bischoff 2016). Images of sails are also known from the Gotlandic Picture Stones, coins, and carved stone graffiti (Kastholm 2016: 120-1). The shape, and especially the size of the sails have also been discussed (Bischoff 2016; Kastholm 2016), as well as the materials they were made of. An increased production of large sails would have required a larger supply of raw material. Few indicators suggest a previous surplus, which could have been drawn upon, and consequently new husbandry strategies would have been developed, focusing on commodities for textiles. If this hypothesis is correct, this would also have involved an increase in pasture used for sheep, and cultivation of textile crops, which would have left traces visible in the archaeological landscape.

Erik Andersen has estimated that there was a need for one million square meters of sailcloth for Knútr inn rikis (Cnut the Greats's) North Sea Empire in the 1020s and 1030s. The calculation is based on the needs of the entire Danish fleet as well as ships used in commerce, fishing, transport and communication, as well as extra fabric reserved for repairs (Andersen, Milland, Myhre et al. 1989: 12). This seems as an astonishing amount but if correct, it provides a unique perspective and understanding of both the required changes needed for an expanded textile production, as well as to its organisation.

\section{Textile value and textiles as commodity money}

In recent Viking Age economic research, textiles have been included in its complex commodity-money system (Skre 2011: 74). Previously it has been suggested that textiles; together with amber; beads; and copper alloys, did not have enough intrinsic value for commodity-money exchanges, at least not on a scale comparable to real estate, or livestock (Sindbæk 2011: 46). However, when the concept of vaðmál (ON: explained below) is included in the discussion, it becomes clear that textiles were an important part of an exchange system where different textile qualities had different values. Vaðmál is the common name for wool fabrics in various coarser twill qualities that were used for items such as clothing, sails, tents, and furnishings (KLNM 19: 412). Furthermore, primarily during the medieval period vaðmál was used as currency, and its production and trade standards are known from Icelandic medieval law codes such as Grágás (1117-271), Járnsiða (1271-81), Jónsbók (after 1281) and Búalög (13 ${ }^{\text {th }}-19^{\text {th }}$ century) (Hayeur Smith 2019: 252). Some contexts suggest that the economic value may have been introduced already in the late Viking Age (Skre 2011: 74; Hayeur Smith 2019: 268). According to Michèle Hayeur Smith (2019: 254), one unit of vaðmál corresponded to two ells in width and six ells in length (one legal Icelandic ell $=49.2 \mathrm{~cm}$ ) in the earliest Icelandic regulations of cloth currency. Its prize in the late Viking Age/early medieval period was one eyrir. This value was similar to the contemporary value 
of Norwegian vaðmál (Hoffmann 1974: 195; Hayeur Smith 2019: 254). According to Dagfinn Skre eight aurar equals one mark silver = c. 214 g (Skre 2011: 73), which consequently suggests that eight units of vaðmál would have had a value of c. $214 \mathrm{~g}$ silver.

Vaðmál came in many different qualities, each priced differently, depending on the number of threads per ell (Hoffmann 1974; Øye 2016:24; Hayeur Smith 2019:268). Unfortunately, since qualities most likely would have changed, a direct comparison between different time periods is not possible, and to further complicate matters, very few textiles are preserved from Viking Age Iceland. However, the few archaeological textiles that have been found in Icelandic Viking Age settlements and harbour areas demonstrate a use of twills with between 4.5 and 14 warp threads, and fewer weft threads. The warp of those fabrics is generally very hard spun while the weft is thicker and more loosely spun, and the variations could be interpreted as different vaðmál qualities (Hoffmann 1974: 213; Øye 2016: 249), which is corroborated since similar types have been found in, for instance, the harbour and settlement area in the Viking age settlement Hedeby, in present day Schleswig-Holstein (Hägg 1984). This also suggest that the production of vaðmál was not exclusive to Iceland or Norway. Still, the disconnect between textual and archaeological evidence makes it difficult to apply the knowledge of the medieval vaðmál, and its economic value, to Viking Age textiles. However, when applied to textile requirements of one ship it can provide a hypothetical value that is important to include in a discussion of the value of textiles in the Viking Age.

\section{Methods and material - an interdisciplinary approach}

My point of departure is the lavishly equipped high-status ship burial in Ladby, Denmark. The ship has been dated to the first half of the $10^{\text {th }}$ century and it is considered to have had a crew of at least 33 (Sørensen 2001: 15; Andersen 2001: 230). Erik Andersen has estimated that the size of the sail was 61 square metres (Andersen 2001:228).

I will estimate the amount of raw materials needed for clothing, sailcloth and other textiles needed for a journey over the North Sea, as well as the time it took to produce the items. The use of different types of textiles is illustrated by a few quotes from Egils saga, which is said to span the time period from c. AD 850 to 1000, thus including the era of the Ladby ship. Finally, I will perform a hypothetical calculation of the economic value of the textiles needed for one North Sea journey on the Ladby ship, based on the value of vaðmál.

Any well-preserved ship from this time period would have sufficed. However, the Ladby ship is one of the best preserved and well-investigated Danish Viking Age ships, and therefore suitable for this study. Even though the ship was used in a burial, detailed analyses clearly demonstrate that this ship could have been used for travel (Sørensen 2001: 15).

Despite being fully aware of women travelling and taking part in battles during this era; I have chosen to base my calculations solely on male garments. The inclusion of female garments could be an interesting and important task for another study.

Obviously, different types of textiles required different raw materials, which affected production time, and consequently the value, but how is this visible in the archaeological context? For my interdisciplinary approach it is not sufficient to focus on one single material, one single object category, or one theory. In order to reach my goals, different research fields and disciplines will be included. This approach is essential for the understanding and interpretation of the production and value of the textiles. 
Below, different written, iconographic and ethnographic sources and materials will be combined with experimental archaeology, and results from earlier research and its analyses of the archaeological textile materials (Hägg 1984; Bender Jørgensen 1986; Andersson 2003; Nørgård 2016). Due to lack of complete, preserved textiles; sailcloth; and clothing, the interpretation of garment and sail design is based on iconography (Mannering 2016; Kastholm 2016; Vedeler 2019), as well as experimental archaeology (Nørgård 2016). Ethnographic analogies between different types of nautical clothing are used since they can provide interesting insights and perspectives on the Viking Age clothing used at sea (Hoffmann 1974; Trætteberg 1999). I will rely on translations and relevant scientific research in my use of Old Norse texts, such as Icelandic Sagas, and law codes. These are important for the understanding of clothing cultures of the past and may provide an indication of the value of the textiles. My discussion on the value of textiles is based on Viking Age economic research (Hoffmann 1974; Skre 2011; Sindbæk 2011; Hayeur Smith 2019).

It is of course important to observe source-critical aspects in the use of all research materials and sources. Special attention is required regarding Icelandic sagas and early medieval laws, since they contain layers of information from different eras, and were not written down until the medieval period. It also has to be considered that the fragile archaeological textile material mainly derives from burials, and does not necessarily reflect every-day items. The same applies to the iconography displayed in objects such as tapestries, which depicts special and perhaps not normal circumstances. However, combined and with a source critical approach, these methods and materials may contribute to new insights and perspectives helpful for our interpretation of the value and demand for textiles in the Viking Age.

\section{Analyses and results}

The following text includes a general description of the Ladby ship's requirements for clothes, sails, tents and other types of textiles, based on textual sources, iconography, and archaeological material. Also, to better understand production processes, I have included results and calculations based on experimental archaeology. With this premise, the production and completion of one complete male outfit required 16.5 square metres of fabric and 1,630 hours (Table $1 \mathrm{a}$ ), or somewhat less fabric but more hours (Table $1 \mathrm{~b}$ ), depending on the design. Nautical clothing for one seafarer required even more fabric (30.5 square metres) and took 3,343 hours to produce (Table 2).

This allows me to estimate which types, and the quantity, of textiles required for the Ladby ship and her crew. When including fabric for one sail, and a spare of a similar size, as well as the clothing for 33 people, no less than $331 \mathrm{~kg}$ of raw materials were required for the production of more than 1,128.5 square metres of fabric, which would have taken 118,615 hours to produce (Table 3 ). It is important to note that the procurement and preparation of fibres, as well as the sewing, is not included in these calculations, which would undoubtedly add considerably to the manufacturing time. However, what is clearly demonstrated is that one single ship required a vast amount of textiles, and when compared with estimated prices of contemporary vaðmál the cost would have been more than $5 \mathrm{~kg}$ of silver (Table 4).

These calculations are based on the value of the Icelandic vaðmál and ell during the late Viking Age/early medieval period, and the question is how this corresponded to the value 


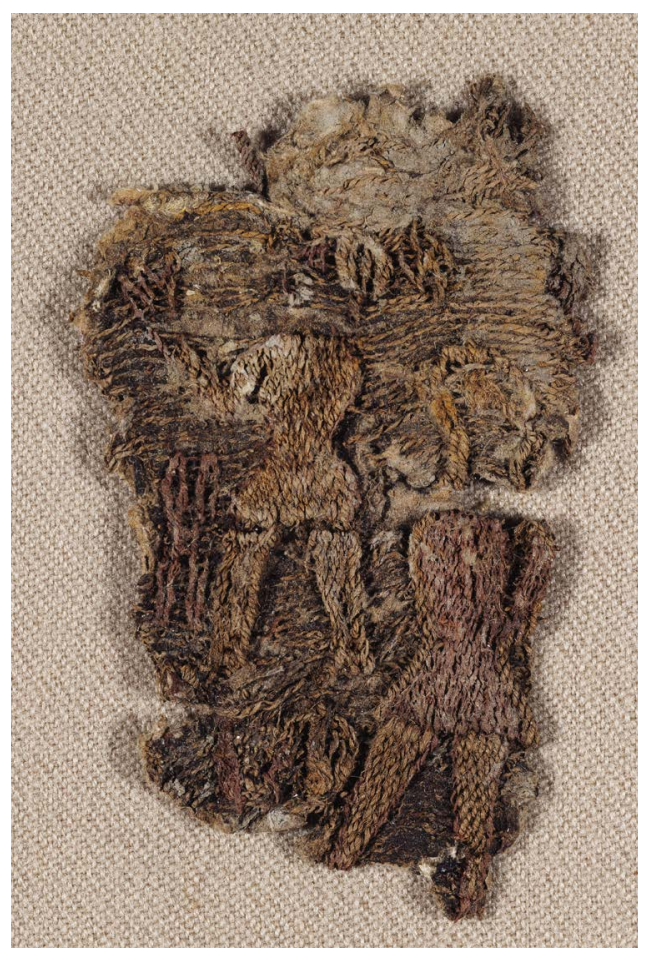

Figure 1. Male figure from the Oseberg tapestry. Photography: E. I. Johnsen, Museum of Cultural History, University of Oslo. CC BY-SA 4.0 and ell used in Viking Age Ladby? Another aspect is that the calculations are based on the value of new textiles, and that the longevity of the fabrics is not taken into account. I was also challenged by the fact that the estimates could only be based on the material of a finished garment, which means that the amount of raw material, and the manufacturing times, would have been much greater. Moreover, a finished sail probably had a much higher value than simply that of its fabric. Also touched upon in the method section, is how, or whether travel and battle garments differed from everyday clothes? In spite of all these reservations the results demonstrate that a single journey with the Ladby ship required a substantial amount of textiles of considerable value.

\section{Clothes for everyday use - garments for} travel, war and warfare

During this time period it is likely that each individual was responsible for his/her own clothing, also while travelling and in battle.

In battle, it was important to wear armour - or other types of protective clothing - to screen the body from blows and punches, and the garments worn underneath must have been equally important. Such clothes would have been well made, strong, and perhaps also padded to cushion pounding, but at the same time easy to move in. Indeed, archaeological analyses have revealed that jackets were padded, in some cases even with down (Hägg 1984: 48-55), and such jackets would also have been useful in cold weather.

In the Icelandic sagas it is often mentioned that the Norse were dressed in battle clothes, or armour, but the texts do not provide any information about the design of such outfits, only that there were differences in armour. One such example comes from Egils saga (Jónsson 1946: ch. 53):

En er ljóst var pá sá varðmenn peira Dórólfs hvar herrinn fór; var pá blásinn herblástr ok herkloeddusk menn, tóku siðan at fylkja liðinu ok hofðu tvar fylkingar.

At daybreak Thorolf and Egil's guard saw the army approaching. Trumpets were sounded and the troops put on their armour, then formed into two columns.

Later in the same section:

Egill hafði inn sama búnað sem Dórólfr. [...]. Hvárrgi peira hafði brynju. Egil was equipped like Thorolf. [...]. Neither of them wore a coat of mail. 
As has been stated before, it is difficult to distinguish between clothes for everyday use and those for warfare. However, some guidance is perhaps found in the Bayeux tapestry - which depicts the 1066 battle of Hastings, as well as its background story - and the Oseberg tapestries, which were made more than 200 years earlier. A comparison between the two reveals that the garment designs had changed but only in parts. Moreover, the Bayeux tapestry shows that the Normans were not dressed in armour as they boarded the ships or during the crossing of the English Channel, but rather in their ordinary (?) clothes. However, in the scenes where the men are riding into battle they are dressed in armour, and in the battle scenes both Normans and Saxons are shown wearing armour. In all other scenes they are wearing multi-coloured garments, tight trousers, and long tunics, all probably made of textiles.

Furthermore, it is important not to forget - especially when studying travel clothing that the basic but essential requirement of garments is to protect the body, and that during sea travel it is important to wear warm and waterproof clothes. In cold weather it is especially important to protect the head since $50 \%$ of temperature loss can be attributed to not wearing head cover. Prolonged exposure to an external temperature below $12^{\circ} \mathrm{C}$ makes the human body weak and powerless, and wind and rain increase the risk for hypothermia. The brain and body work best at $37^{\circ} \mathrm{C}$, below $37^{\circ} \mathrm{C}$ the body and brain function will slow down, and below $33^{\circ} \mathrm{C}$ unconsciousness sets in (Kahl and Horn 1998: 4-5). When crossing the North Sea this could happen even during the summer months, especially in the event of storm and rain. To dress properly must have been even more important when sailing in open ships. This makes it quite plausible that special clothing was worn during sea crossings under sail, as is mentioned in some early accounts (Falk 1995: 17). It is quite likely that such clothes were used already in the Viking Age, especially on longer journeys. The nautical clothing that is mentioned in different medieval texts was generally made of leather, although the texts do not contain any information regarding the design of such garments (Falk 1995: 17). The Norwegian ethnologist Gunvor Ingstad Trætteberg researched the outfits worn by $18^{\text {th }}$ century fishermen in Northern Norway. According to her research, next to the body these men wore clothes made of wool (a soft shirt, a thick robe, trouser, puttees, a cap and gloves) but their outer garments were made of leather (trousers, a robe, and a rain cap). She concludes that it is likely that similar types of garments were used in earlier periods and that their design would have resembled those of the garments from $18^{\text {th }}$ century Northern Norway (Trætteberg 1999, in Gjaerum 2006).

Old Norse texts also contain sea-battle accounts of Norse warriors falling overboard wearing mail coats and armour (Jesch 2001: 212). It is, however, unlikely that iron armour, such as chain mail, would have been worn during sea travel, due to its susceptibility to rust and its weight when falling overboard. Besides the clothes they wore, the sailors would have brought extra clothes, which they kept in sea-chests together with weapons and food (Falk 1995: 17).

To conclude, although some texts provide general information regarding garments, for instance of well-dressed Rus' wearing kaftan-like jackets and wide trousers (Androshchuk 2004: 37), or Norse wearing travel clothing, mantles, etc. (Jóhannesson, Hansson, Johansson et al. 2014), it is difficult to find detailed information on Scandinavian garment traditions. Additionally, the recorded texts are - as previously mentioned - not contemporary and may not reflect the true fashion of the Viking Age. With the exception of nautical clothing, noth- 
ing indicates that clothes worn during travel or war would have been of a different design than the everyday clothing. Instead, the differences are visible in the use of armour and other dress accessories. It is of course likely that extra garments were brought on journeys, and for war, but spare clothes must have been required at home as well. For those of higher rank, everyday clothing would have been made of higher quality fabrics, but despite status, such garments still needed to be warm and functional. In order to understand Viking Age garment design, other sources, such as iconography, have to be used.

\section{Garments, design and iconography}

The best information regarding Viking Age clothing design comes from iconography. In her work ICONIC Costumes, Scandinavian Late Iron Age Iconography, Ulla Mannering has studied various figurative object categories, mainly jewellery, and tapestries from the Viking Age. Her studies of tapestries have revealed men wearing cloaks, wide breeches, or narrowed-legged trousers, both over and under tunics of different lengths. Her analyses of depictions on jewellery have revealed men wearing trousers, and tunics, or blouses (Fig. 1). Furthermore, different types of kaftans have also been documented, especially from gold foil figures, and helmet plates, dated to AD 500-950 (Mannering 2016). Her suggestions are supported by Marianne Vedeler's and Björn Hougen's studies of the Oseberg tapestries, dated to the first half of the $9^{\text {th }}$ century, which also contain these types of garments (Hougen 2006; Vedeler 2019: 37-9).

\section{Reconstruction of Viking Age Male Clothing}

The knowledge gained from textile analyses, and from textile fragments, provide information about fibre qualities and production techniques (Hägg 1984; Bender Jørgensen 1986). Through reconstructions based on these parameters, it is possible to make rough estimates regarding the quantity and weight of the required raw material. Complete reconstructions - from fibre to finished garment - are, however, very unusual since they take a very long time to produce, and are very costly (Demant and Batzer 2015).

In the Lejre Land of Legends (Danish: Sagnlandet Lejre), in Denmark, several male outfits have been reconstructed based on analyses of archaeological textile fragments from Hedeby (Hägg 1984; Demant and Batzer 2015). Reconstructions of two Viking Age male outfits made at the Lejre Land of Legends have been chosen for my calculations on raw material consumption and production time for the Ladby ship crew's clothing. The amount of fabric that the outfits required depended, of course, on the person wearing them. My reconstructions are based on a person around $175-80 \mathrm{~cm}$ tall, of normal weight.

With regard to the number of threads per centimetre and weaving technique the reconstructed materials are approximately the same as the originals, but the fabrics are also partly made with either machine spun yarn, and/or woven on a horizontal treadle loom. The time estimate is therefore based on the manufacture of similar fabrics, spun and woven with tools and raw materials known from Viking Age archaeological finds (Andersson Strand 2003; Nørgård 2016).

It is important to note that generally a machine spun yarn is lighter than a hand spun one. Furthermore, since the estimates are based on finished clothes, not taking into account that a substantial part of the raw material would have been lost during the preparation processes, as well as during spinning and weaving. This implies that the estimated weight is a mini- 


\begin{tabular}{|l|l|l|l|l|l|}
\hline $\begin{array}{l}\text { A) Suggested male } \\
\text { garment }\end{array}$ & Weight (g)* & $\begin{array}{l}\text { Weaving } \\
\text { technique }\end{array}$ & Threads per $\mathrm{cm}$ & $\begin{array}{l}\text { Fabric needed } \\
\left(\mathbf{m}^{2}\right)\end{array}$ & $\begin{array}{l}\text { Time consumption } \\
\text { (hours) }\end{array}$ \\
\hline Cloak, wool & 1400 & $2 / 2$ & $9 / 9$ & 7.5 & 750 \\
\hline Overtunic, wool & 880 & $2 / 2$ & $19 / 11$ & 2.5 & 387.5 \\
\hline Under tunic, linen & 440 & tabby & $8 / 8$ & 2.5 & 250 \\
\hline Breeches, wool & 800 & tabby & $25-18 / 18-8$ & 3 & 142.5 \\
\hline Puttees, wool 3.6 m & 135 & $2 / 2$ & $11 / 6$ & 1 & 100 \\
\hline Total & 3,655 & & & 16.5 & 1,630 \\
\hline $\begin{array}{l}\text { B) Suggested male } \\
\text { garment }\end{array}$ & Weight (g) $)^{*}$ & $\begin{array}{l}\text { Weaving } \\
\text { technique }\end{array}$ & Threads per cm & $\begin{array}{l}\text { Fabric needed } \\
\left(\mathbf{m}^{2}\right)^{* *}\end{array}$ & $\begin{array}{l}\text { Time consumption } \\
\text { (hours) }\end{array}$ \\
\hline Jacket, wool & 1500 & $2 / 2$ & $17 / 6-7$ & 6.5 & 994.5 \\
\hline Trousers, wool & 380 & $2 / 2$ & $14 / 7-8$ & 2 & 306 \\
\hline Long sleeved tunic, wool & 960 & $2 / 2$ & $16-17 / 6$ & 2.5 & 382.5 \\
\hline Under tunic, linen & 440 & tabby & $11 / 6$ & 2.5 & 142.5 \\
\hline Puttees, wool 3.6 & 135 & $2 / 2$ & $11 / 6$ & 1 & 100 \\
\hline Total & 3.415 & & & 14.5 & 1.925 .5 \\
\hline
\end{tabular}

Table $1 a$, and $1 b$. Two types of male outfits based on reconstructions of textiles from Hedeby, made at the Lejre Land of Legends, Denmark. * The raw material consumption was calculated based on the weight of the reconstructed clothes ** The amount of fabric needed to produce the different clothes ***The hours required to spin and weave the fabrics. The estimate of spinning and weaving time is based on textile reconstructions made at the Viking Ship Museum, Roskilde Denmark (Nørgård 2016).

mum one, that the original would have been heavier, and that more raw material would have been required. This means that the estimates are hypothetical, although they still provide an idea of how much fabric and time it took to produce a garment of simple design, using a minimum of raw materials.

The table illustrates the significant amount of raw materials and production time required even for a minimum investment in clothes for everyday use. One male garment required 16.5 square metres of fabric, and took 1,630 hours to produce (Table $1 \mathrm{a}$ ), or somewhat less fabric but more hours (Table $1 \mathrm{~b}$ ), depending on the design (Table $1 \mathrm{a}$ and b; Fig. 2).

\section{Sails, tents and extra fabric}

There is no doubt that the sails were of great importance for the Viking Age, and that they, like the ships, were very valuable. Sails and sailing are mentioned in the Icelandic sagas and other medieval texts, as below in Egils saga (Jónsson 1946: ch 17): 

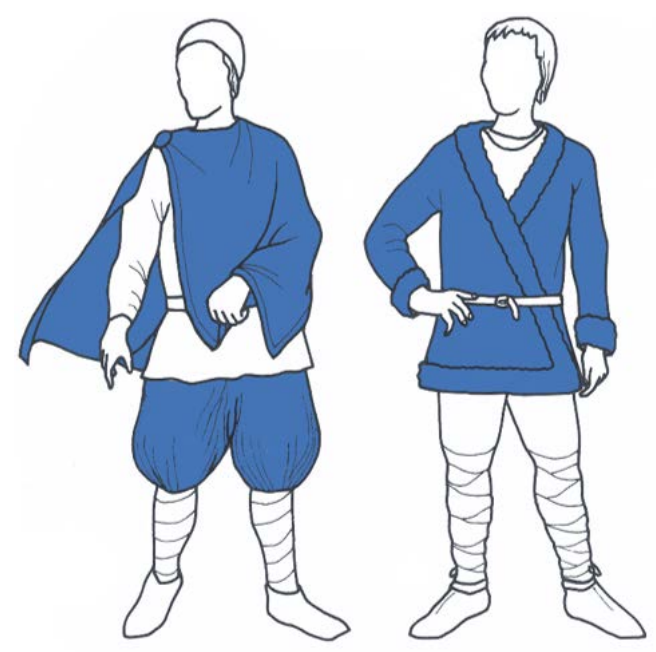

Figure 2. Illustrations of the outfits in table 1 and 1 b. (After Hägg 1984 and Hägg's drawings in Elsner 1989, redrawn by Sidsle Frisch.)

Pórólfr átti skip mikit. Pat var lagt til hafs. Pat var vandat at öllu sem mest, steint mjök fyrir ofan sjó. Dar fylgði segl stafat með vendi blám ok rauðum. Allr var reiði vandaðr mjök með skipinu.

Thorolf owned a big ocean-going ship, which was lavishly equipped, richly painted above the plumbline and fitted with a black-and-red striped sail. All the riggings were well designed.

Egils saga (Jónsson 1946: ch 67 (or 68 in this English translation)), also mentions that sails were given as gifts:

Egill hafði látit gera langskipssegl mjök vandat. Segl pat gaf hann Arinbirni ok enn fleiri gjafar, par er sendiligar váru.

He had had a very ornate sail made for a longship and gave it to Arinbjorn, together with other fitting gifts.

The quality requirements of the sailcloth were high, since - among other things - a sail had to keep its shape and not be too elastic. Other important factors were how windproof it was, and that it did not provide too much friction. A sail should also be as light as possible, to catch the wind more easily but still sturdy enough for the size of ship, and as waterproof as possible, in order not to gain a lot of weight in wet weather (Bohlmann 2016: 163-4).

In general, it is assumed that the sails were made of wool (Falk 1995: 77; Jesch 2001: 163; Andersen and Bischoff 2016: 138) although the use of flax or hemp should not be excluded. Based on medieval texts, Hjalmar Falk has suggested that the more exclusive materials, such as flax, may have been reserved for high status ships, such as royal ones (Falk 1995: 78). Very few Viking Age textile fragments that can be interpreted as sailcloth have been found in Scandinavia. The most famous finds are from the Oseberg burial, although it is debated whether they are remnants of sailcloth or tents (Fig. 3) (Möller-Wiering 2002; Bender Jørgensen 2012; Andersen and Bischoff 2016). It is, however, likely that the quality would have been more or less the same, since the fabric needed in both cases had to be dense and waterproof. Due to the uncertainties listed above, and the lack of originals, the assumptions about the quality of Viking Age sails are partly based on preserved sails from later time periods (Möller-Wiering 2002; Bender Jørgensen 2012; Andersen and Bischoff 2016). 


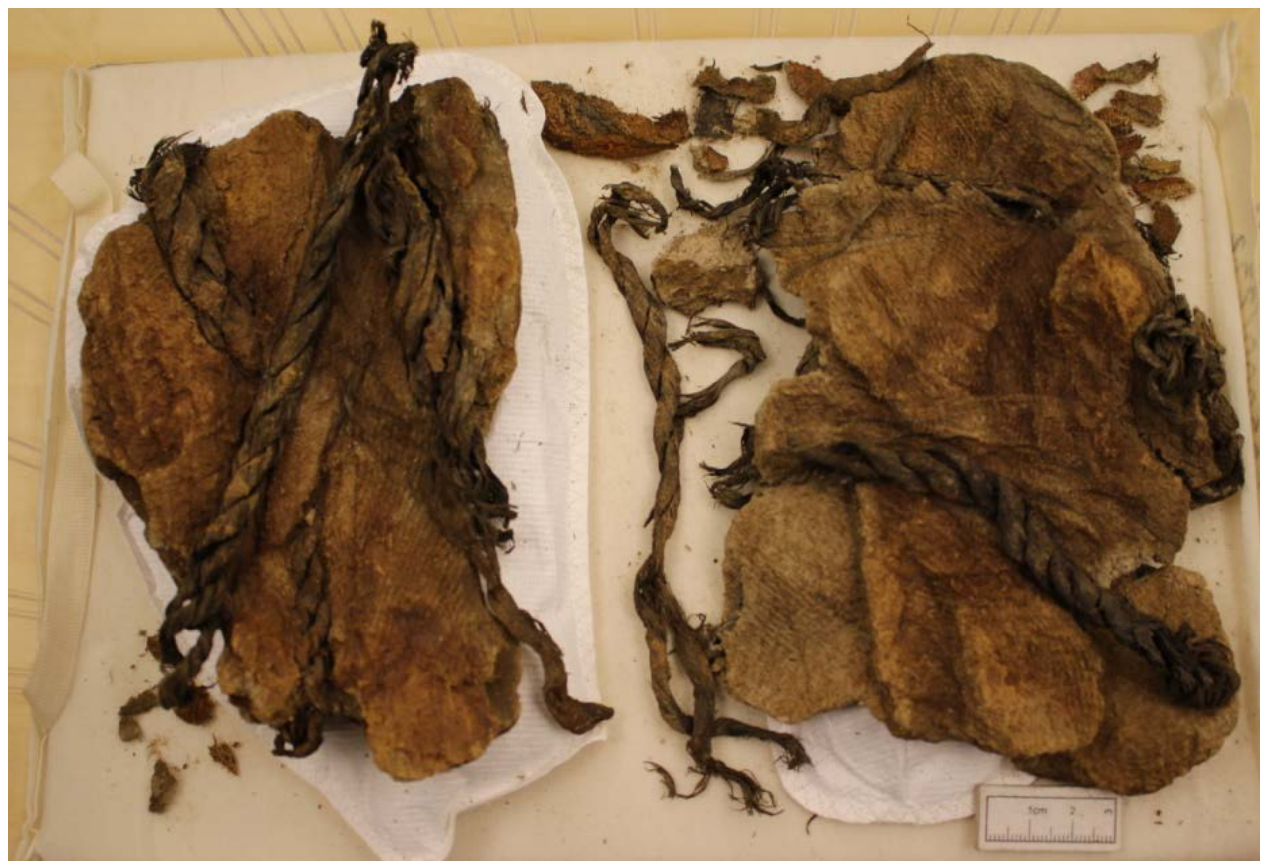

Figure 3. Sailcloth and/or tent cloth from the Oseberg burial. Photography: Charlotte Rimstad. I thank Marianne Vedeler, Museum of Cultural History, University of Oslo, for kindly allowing access to the Oseberg textile collection.

The use of tents or covers for the night is frequently mentioned in the sagas. There are texts that mention their use on land, but often the crews seem to have stayed on the ships (Falk 1995; Jesch 2001), as in Egils saga (Jónsson 1946: ch 27): Peir Hallvarðr höfðu tjaldat yfir skipi sínu ok höfðu pá lagízt til svefns. 'Hallvard and his men had covered the ship with awnings and gone to sleep, [...]'

What was used as tent cloth is also debated, and it has been argued that the sails may have served as tents (Falk 1995: 18-20; Jesch 2001: 164). In Old Norse, the word tjald can refer to wall-hanging, but it can also refer to a ship's cover, an awning or a tent (Falk 1995: 18-20). Judith Jesch argues that the word tjald could also have referred to a sail, implying that the textiles used as covers or tents were the sails (Jesch 2001: 164). Another possibility is that spare sails were used to cover the ships (Jesch 2001: 164). The medieval text, called the King's Mirror (Larson 1917: ch. 4), states:

There remain a few minor matters that ought to be mentioned. Whenever you travel at sea, keep on board two or three hundred ells of wadmal of a sort suitable for mending sails, if that should be necessary, a large number of needles, and a supply of thread and cord. It may seem trivial to mention these things, but it is often necessary to have them on hand.

Even though the text is dated to the $13^{\text {th }}$ century, it is obvious that extra cloth was required on sea journeys, most importantly for mending sails. It is highly unlikely that this was a new 
medieval phenomenon since sails had to be mended in the Viking Age as well, and it is likely that such extra cloth may have been used as tent cloth.

As with sailcloth, no confirmed finds of an intact tent cloth have been registered but, as previously mentioned, it can be assumed that the fabric was of a similar quality and type as the sailcloth. Furthermore, only a few finds, from Oseberg and Gokstad, have been interpreted as tent frames. Several reconstructions based on these frames have been made and the fabric needed for one of the smaller tents is c. 50 square metres (Fotevikens Viking Museum, no date).

\section{Estimates and discussion - The Ladby Ship and the textiles required for one journey}

\section{Clothing}

Apart from the clothes they wore, it is likely that each crewmember brought at least one extra set of clothes on a journey. Based on archaeological analyses of textiles in combination with experimental archaeology, it has been estimated that each crewmember had a minimum of clothes representing more than $6.5 \mathrm{~kg}$ of raw materials, or 30.5 square metres of fabric, which would have taken 3,343 hours to spin and weave (Table 2). Furthermore, well-made nautical clothing, possible of leather, and sleeping covers would have been necessary for survival. If all crewmembers would have brought the same amount of clothes and outfits, this equated to $215 \mathrm{~kg}$ of raw material, requiring more than 11,000 spinning and weaving hours (Table 3 ).

\section{Sailcloth and spare fabric}

The sail size of the Ladby ship has been estimated to 61 square metres (Andersen 2001: 228). It is not clear whether the sail was made of wool or plant fibres but many small plainweave fragments of different qualities were found during the excavation of the ship. Unfortunately, the type of fibre has not been established (Sørensen 2001: 72). In general, plant-fibre fabrics are woven in plain weave and not in twill, while wool fibrefabrics are woven in both. This makes it impossible to conclude whether the Ladby sail was made of wool, or plant fibres. However, it does not exclude Falk's interpretation that some high status ships could have had plant-fibre sails (Falk 1995: 78).

The analyses of the textile fragments from Ladby reveal a thread count of 8-20 threads in warp and 6-20 threads in weft, which indicates that a variety of fabrics and qualities were used (Bender Jørgensen 1986: 255). Especially the coarser qualities of 8/6 threads per cm could be considered as a sailcloth quality.

According to Anna Nørgård, from the Viking Ship museum in Roskilde, a wool 61 square metre sail, woven in a twill with 8 threads in warp and 5 threads in weft, would take c. 4,148 hours to spin and weave. The preparation of the yarn, warping, and set-up would add another 830 hours. Altogether, it would take her c. 5,000 hours, or 416 days to make such a sail if she would work twelve hours a day (Nørgård 2016). However, if weaving in a tabby the spinning and weaving would only take c. 3,477 hours, excluding the 830 hours needed for preparation of the fibres, warping and set-up.

If six crew members of the Ladby ship were housed in each tent, a total of 5-6 tents and 250-300 square metres of cloth would have been required to shelter them all. That is a substantial amount of cloth, especially when considering that another 61 square metres of spare 


\begin{tabular}{|c|c|c|c|}
\hline Clothes for sea travel & & & \\
\hline Textiles & Weight $(g)^{*}$ & Fabric needed $\left(\mathrm{m}^{2) * *}\right.$ & Time consumption (hours) ${ }^{* * *}$ \\
\hline Cloak or blanket & 1,400 & 7.5 & 750 \\
\hline Jacket & 1,500 & 7.5 & 994.5 \\
\hline Trousers & 380 & 2 & 306 \\
\hline Long sleeved wool tunic & 960 & 2.5 & 382.5 \\
\hline An extra long-sleeved wool tunic & 960 & 2.5 & 382.5 \\
\hline Under tunic +2 extra & $1,200(400 \times 3)$ & 7.5 & 427.5 \\
\hline Puttees & 135 & 1 & 100 \\
\hline Cap & $?$ & $?$ & \\
\hline Gloves & $?$ & $?$ & \\
\hline \multirow[t]{2}{*}{ Socks } & $?$ & $?$ & \\
\hline & $>6,535$ & $>30.5 \mathrm{~m}^{2}$ & $>3,343$ hours \\
\hline \multicolumn{4}{|l|}{ Leather/skin } \\
\hline \multicolumn{4}{|l|}{$\begin{array}{l}\text { One set of sea cloths including a } \\
\text { jacket, trousers and a rain cap }\end{array}$} \\
\hline \multicolumn{4}{|l|}{ Shoes and/or Boots } \\
\hline A sleeping cover & & & \\
\hline
\end{tabular}

Table 2. The minimum amount of clothes needed for one person on a journey * The amount of raw material is calculated on the weight of the reconstructed clothes ** The amount of fabric required to produce the different clothes $* * *$ The hours required to spin and weave the fabrics **** These garment types ought also to be included but due to the lack of finds and reconstructions they are excluded. The estimations of spinning and weaving time is based on textile reconstructions made at the Viking Ship Museum, Roskilde Denmark (Nørgård 2016).

cloth would have been brought along. This indicate that either the sail, and/or the spare sailcloth may have been used as awnings aboard the ship, which would have reduced the amount of fabric needed for shelter.

The value of the textiles on the Ladby ship

As previously stated my aim is to discuss the requirements for - and the economic value of - all the textiles for one journey on one single ship. To illustrate this, an estimate of the basic and minimum need for textiles on one ship with 33 crewmembers is made below in table 3 . This included clothes, sail, and spare fabric, while banners and textiles for caulking and wrapping are excluded. The estimates are based on the production of wool fabrics, through spinning and weaving, on a warp-weighted loom. They only represent the amount of raw 


\begin{tabular}{|l|l|l|l|}
\hline & Raw material $(\mathbf{k g})^{*}$ & Fabric needed $\left(\mathrm{m}^{2}\right)^{* *}$ & No. of spinning and weaving hours $* * *$ \\
\hline Clothes & $>215$ & $1,006.5$ & 110,319 \\
\hline Ladby sailcloth wool & $>58$ & 61 & 4,148 \\
\hline Spare fabric wool & $>58$ & 61 & 4,148 \\
\hline Summary wool textiles & $>331$ & $1,128.5$ & 118,615 \\
\hline Ladby sailcloth linen & $>43$ & 61 & 3,447 \\
\hline
\end{tabular}

Table 3. The minimum of raw materials and fabrics to cover the requirements of the Ladby ship if using a wool sail and a spare cloth of the same size. It also includes the time needed to produce the textiles. * The amount of raw material is based on the weight of the reconstructed clothes. ** The amount of fabric needed to produce the different clothes. ***The hours needed to spin and weave the fabrics. The estimate of spinning and weaving time is based on textile reconstructions made at the Viking Ship Museum, Roskilde Denmark (Nørgård 2016).

material and time needed for the finished textiles, excluding waste. Hence, the estimates can be said to represent an absolute minimum of raw material, time and fabric required.

The need for raw material was still substantial; c. $331 \mathrm{~kg}$ of raw material equates to wool from 331 sheep. According to modern calculations these sheep would need 33.1 hectares of well-fertilised pasture (10 sheep/hectare (Bender Jørgensen 2012; Fag undated). Even if the Viking Age sheep were half the size of modern sheep, and only used half the pasture, more than 16.5 hectares were needed (20 sheep/hectare).

If plant fibres were used for the sail, more than 700 square metres of land would have had to be cultivated (calculation based on Fröier and Zienkiewicz 1991), and since the calculation is based on modern cultivation the Viking Age yield would have been lower requiring even more land.

The value of the textiles needed for a journey on the Ladby ship can of course only be hypothetically discussed, based on newly made textiles. Using the estimate of the minimum of textiles required for the Ladby ship, and the value of Icelandic vaðmál in the late Viking Age/early medieval period, the value for the textiles can be calculated to c. 187 aurar, the equivalent of c. $5 \mathrm{~kg}$ of silver (Table 4) (Skre 2011: 73; Hayeur Smith 2019: 254).

The time it would have taken to produce these textiles is equally substantial. Sailcloth would have been a standardised product since one cannot use one type of fabric in one end of the sail and another type in the other. During the Viking Age most clothing textiles are considered to have been produced in a household context but the production of sails would have required both a surplus of raw materials, an available workforce, and a new organisational mode. It is likely that the production was organised as a household industry, or as a putting-out system (Andersson Strand 2016). Several craft people would have been involved, some for preparing and combing the fibres. Others, such as spinners and weavers, would have used standardised tools in order to produce the same type of fabric, which would certainly have sped up production. If, for instance four craft people, working twelve hours a day, were involved in the production of the Ladby sail, the spinning and weaving would have taken less than 3 months. Specialists may have worked even faster and pro- 


\begin{tabular}{|l|l|l|l|l|}
\hline & Ells of fabric needed & Units of legal vaðmál (2x6 ells) & Number of 8 units vađmál & Value 8 aurar $=214 \mathrm{~g}$ silver \\
\hline Clothes & 2,012 ells & c. 167 & c. 20.8 & c. $4.4 \mathrm{~kg}$ \\
\hline Sailcloth & 124 ells & c. 10 & c. 1.25 & c. $0.27 \mathrm{~kg}$ \\
\hline Spare fabric & 124 ells & c. 10 & c. 1.25 & c. $0.27 \mathrm{~kg}$ \\
\hline Total & 2,260 ells & c. 187 & c. 23.3 & c. $4.98 \mathrm{~kg}$ \\
\hline
\end{tabular}

Table 4. All the textiles needed for Ladby crew, including sail and spare cloth and their hypothetical value when calculated on legal ells, and the silver value based on aurar (Skre 2011: 73; Hayeur Smith 2019: 254). Please note that it is the Icelandic contemporary ell (49.2 $\mathrm{cm})$ is used for the estimates.

duced more in a shorter time. Still, it is a substantial amount of time if four people would spend three months of a year on spinning and weaving. It is also important to note that the time for procurement and preparation of fibres, the set-up in a loom and the finishing, is not included. Such processes were also time-consuming, and would undoubtedly have involved even more people (Andersson Strand and Demant in prep.).

Another important factor is for how long textiles, clothes, and sails would have been in use. It is unlikely that all clothes were new. Clothes made of wool and plant fibres can be used for a very long time - in fact several years - especially if they are not washed (Ida Demant, personal comment). A well-made wool sail is said to last for 20-5 years, and a wool jacket several years. Still, while old textiles constantly would have had to be replaced, it is impossible to estimate how often for each individual (Andersen 1989; Demant personal comment). Textile analyses have revealed that Viking Age textiles were mended and resewn until they were falling apart, and when no longer useful as clothing, they were, among other things, used as caulking, or as brushes for taring the ships (Hägg 1984; Sørensen 2001).

\section{Conclusion}

The conclusion is that the amount of textiles required for sea travel was substantial. However, whether special clothes were used for those journeys, and in battle, is not possible to ascertain through this study, and the same applies for how much extra clothing was brought and used. Nautical clothing would have been necessary but it was probably made of leather, making its value impossible to estimate within the context of this study. The calculations used here only reflect the minimum requirements of travel clothing, and the value of each set of clothing per person - when new - could hypothetically be estimated to c. 130 $\mathrm{g}$ silver. Such estimates make it easier to understand the reasons for textiles being referred to as valuables and given as gifts in the sagas.

It might feel surprising that the estimated value of the fabric for the sail is quite low, c. $270 \mathrm{~g}$ silver. This, however, excludes the value of the sewing and finishing, as well as the ropes required. These would undoubtedly increase the value but by how much is not possible to estimate through this study. Furthermore, as stated above, a spare sail/fabric was probably brought along, which would add another $270 \mathrm{~g}$ silver to the cost. 
It would be interesting if future research could include a study of the farming area around Ladby, and dealt with questions, such as: were all the textiles produced in the region or were some imported; what was the capacity of the local sheep pasture or for the cultivation of flax; what types of tools have been found in nearby settlements; and what was the population of the region around AD 900? A thorough study of the textile production landscape and an ensuing discussion may be able to provide a deeper understanding of such conditions.

Although the awareness of textiles as commodity-money has increased, they are still clearly underestimated in the general discussion of the Viking Age economy. In my opinion it is not surprising that a 'piece of cloth' i.e. vaðmál, became legal currency. The last sentence in the King's Mirror reveals a medieval view of ordinary textiles: 'It may seem trivial to mention these things, but it is often necessary to have them on hand' (Larson 1917). This quote acknowledges the importance and value of textiles but also that they are/were taken for granted and often overlooked in everyday life, until they are/were needed. Handmade textiles commanded a high value, which was diminished through the industrialisation of textile production. This development is reflected in archaeological research where textiles are such essential parts of everyday life - and obvious - that although no one would deny that they are there, they attract little or no attention.

Despite the fact that it is impossible to distinguish between everyday clothing and clothing for travel and warfare, my estimates provide new insights and perspectives. They clearly demonstrate the value of Viking Age textiles, especially clothing, despite not focusing on high status or high quality products. Moreover, the results indicate that the need for raw materials and the production time for the manufacture of ordinary clothes - essential for survival - was considerable. Still, this is not unique for the Viking Age, clothing has always been essential. The novelty is the demand for different types of textile qualities and a new use of raw materials and techniques, demonstrated by thousands of individual samples of various qualities of textiles from Viking Age burials, settlements, and harbours. The sheer number of textile tools - one of the most commonly found artefact categories in Viking Age settlements - provide insight into these novel productional and organisational modes.

This article reveals reasons for the increased need of textiles in the Viking Age, and its impact on society, where several parameters have been included. It aims to initiate a discussion regarding the economic value of the textiles required and used for travel and warfare. Despite some loose ends, and difficulties in distinguishing the requirements for textiles used for travel from those of everyday life, the results demonstrate that it is possible to study the economic value and the impact of textiles in Viking Age Scandinavia through the use of different sources. However, in the interpretation of Viking Age society it is important to include not only the textiles themselves but also other related aspects, such as: production landscape, organisation and economy, social, political, gendered and martial identities, as well as individual and societal needs and desires. By including such perspectives in future research, the perception of this time period, region, and its inhabitants, is likely to become more realistic. 


\section{Acknowledgement}

I wish to express my warmest thanks to my colleagues and friends Ulla Mannering, Marianne Vedeler, and Charlotte Jonson-Hedenstierna for their inspiration and discussions regarding the theme textiles economies. Many thanks to Ida Demant for her valuable help with the estimates, and for sharing her knowledge on the reconstructions made at Lejre. I also wish to thank my colleagues in the research project Fashioning the Viking Age. I am grateful to Fredrik Sundman, who has proof-read this paper. Finally, kind thanks the two anonymous reviewers as well as Karoline Kjesrud and Frode Iversen for their constructive and valuable critique. This research was carried out with the support of Velux foundation, Denmark, and the Centre for Textile Research, Saxo institute, University of Copenhagen.

\section{Note}

1 The Project Fashioning the Viking Age is founded by Velux foundation and hosted at the National museum of Denmark in collaboration with Centre for Textile Research UCPH and Lejre Land of Legends.

\section{Bibliography}

Andersen, Erik, Jytte Milland and Eva Myhre

1989 Uldsejl i 1000 år. Vikingeskibshallen, Roskilde.

Andersen, Erik

2001 Mast and rigging. In Ladby: A Danish Ship-Grave from the Viking Age, Ships and Boats of The North, vol. 3, edited by Anne C. Sørensen, pp. 226-34. Viking Ship Museum in collaboration with the National Museum of Denmark and Kertemindeegnens Museer, Roskilde.

Andersen, Erik and Vibeke Bischoff

2016 Vikingeskibsmuseets sejlforskning: råsejl af uld og plantefibre i vikingetiden. In Vikingetidens sejl, festskrift tilegnet Erik Andersen, Arkæologiska Skrifter 14, edited by Morten Ravn, Lone Gebauer Thomsen, Eva Andersson Strand and Henriette Lyngstrøm, pp. 137-60. Saxo-Instituttet, Københavns universitet, København.

Andersson, Eva

1996 Textilproduktion i arkeologisk kontext, en metodstudie av yngre järnåldersboplatser $i$ Skåne. Institute of Archaeology, Report series No. 58, Lund.

2003 Tools for Textile Production - from Birka and Hedeby. Birka Studies 8. Riksantikvarieämbetet och Statens historiska museum, Stockholm.

Andersson Strand, Eva

2016 Segelduk och segelduksproduktion i arkeologisk kontext. In Vikingtidens sejl, festskrift tilegnet Erik Andersen, Arkæologiska Skrifter 14, edited by Morten Ravn, Lone Gebauer Thomsen, Eva Andersson Strand and Henriette Lyngstrøm, pp. 23-54, Saxo-Instituttet Københavns universitet, Copenhagen.

Andersson Strand, Eva, and Ida Demant

In prep. Textile production and craft people in Viking Age - new analyses and results.

Andersson Strand, Eva, Ulla Mannering and Irene Skals

2017 Forhistorisk tekstilproduktion. In Arkceologisk Tekstilforskning, baggrund og ny viden, edited by Ulla Mannering, pp. 45-79. The National Museum of Denmark, Copenhagen.

Androshchuk, Fedir

2004 Vikings - the Rus - Varangians. In Olga och Ingegerd - Vikingarfurstinor i Öst, Historiska nyheter, Specialnummer 2004, pp. 36-9. Statens Historiska Museum. Stockholm. 
Bender Jørgensen, Lise

1986 Forhistoriske textiler i Skandinavien: Prehistoric Scandinavian Textiles. Nordisk Fortidsminder Serie B Bind 9. Det Kongelige Nordiske Oldskriftselskab, Copenhagen.

Bender Jørgensen, Lise

2012 The Introduction of Sails to Scandinavia: Raw materials, Labour and Land. In N-TAG TEN, proceedings of the 10th Nordic TAG conference at Stiklestad Norway 2009, BAR international Series 2399, edited by Ragnhild Berge, Marek E. Jasinski and Kalle Sognnes, pp. 173-81. Archaeopress, Oxford.

Bischoff, Vibeke

2016 Vikingetidens sej1 - form og proportion. In Vikingetidens sejl, festskrift tilegnet Erik Andersen, Arkæologiska Skrifter 14, edited by Morten Ravn, Lone Gebauer Thomsen, Eva Andersson Strand and Henriette Lyngstrøm, pp. 97-118. Saxo-Instituttet Københavns Universitet, Copenhagen.

Bohlmann, Jörn

2016 Rekonstruksjon av vikingetidens seil - håndverksmessige utfordringer. In Vikingetidens sejl, festskrift tilegnet Erik Andersen, Arkæologiska Skrifter 14, edited by Morten Ravn, Lone Gebauer Thomsen, Eva Andersson Strand and Henriette Lyngstrøm, pp. 161-72. Saxo-Instituttet Københavns universitet, København.

Demant, Ida and Anne Batzer

2015 The Good Garment Reconstruction. In Refashioning Viking Age Garments. Texts to a seminar in the Seed-money network 'Vikingetid i Danmark', edited by Henriette Lyngstrøm, pp. 49-54. The Saxo Institute at University of Copenhagen, København.

Fag, Birgit

No date Att Skaffa får. Hushållningssällskapet Jönköpings län, [http://www.faravelsforbundet.se/

Falk, Hjalmar wp-content/uploads/attskaffafar.pdf], last accessed 03.07.2020.

1995 Fornnordisk sjöfart. Translated by Bo Varenius. Båtdokumentationgruppen, Skärhamn.

Foteviken Viking Museum

No date [https://www.fotevikensmuseum.se/d/en/vikingar/hur/talt/material], last accessed 03.07.2020.

Fröier, K. and H. Zienkiewicz 1991 [1979] Linboken, hemodling och hemberedning. Natur och Kultur. Borås.

Gebauer Thomsen, Lone

2016 Spor efter vikingetidens sejlproduktion på Sjælland. In Vikingetidens sejl, festskrift, tilegnet Erik Andersen, Arkæologiska Skrifter 14, edited by Morten Ravn, Lone Gebauer Thomsen, Eva Andersson Strand and Henriette Lyngstrøm, pp. 55-76. Saxo-insituttet Københavns universitet, København.

Gjaerum Helena

2006 Förslag till vikingatida sjökläder, student paper from Teknik i Forntiden. Bäckedals Folkhögskola, Bäckedal, Sveg. [https://docplayer.se/8241883-Forslag-till-vikingatida-sjoklader. html], last accessed 29.06.2020.

Hayeur Smith, Michèle

2019 Vaðmál and Cloth Currency in Viking and Medieval Iceland. In Silver, Butter, Cloth Monetary and Social Economies in the Viking Age, edited by Jane Kershaw and Gareth Williams, pp. 251-77. Medieval History and Archaeology, Oxford University Press. Oxford.

Hoffmann, Marta

1974 [1964] The warp-weighted loom: studies in history and technology of an ancient implement. Robin and Russ Handweavers, Oslo.

1975 Vadmål, KLNM, XIX: 409-12.

Hougen, Björn

2006 Billedvev. In Osebergsfunnet Bind IV Tekstilene. Oslo, edited by A. E. Christensen and M.

Nockert, pp. 15-141. Kulturhistorisk Museum Universitetet, Oslo. 
Hägg, Inga

1984 Die Textilfunde aus dem Hafen von Haithabu, mit Beiträgen von G. Grenander Nyberg und H. Schweppe. Berichte über die Ausgrabungen in Haithabu, Bericht 20. K. Wachholz, Neumünster. Jesch, Judith

2001 Ships and Men in the Late Viking Age, the Vocabulary of Runic Inscriptions and Skaldic Verse. Boydell \& Brewer, Suffolk.

Jóhannesson Kristine, Gunnar D. Hansson and Karl G. Johansson

2014 Islänningasagorna: samtliga släktsagor och fyrtionio tåtar, In Skalder, Grönland Vinland. Saga forlag. Reykjavik

Jónsson, Guðni

1946 Egils saga Skalla-Grimssonar, in Old Norse, [https://heimskringla.no/wiki/Egils_saga_SkallaGrímssonar] last accessed 03.07.2020.

Kastholm, Ole T

2016 Sejlform og skibstype - tradition og fornyelse. In Vikingetidens sejl, festskrift tilegnet Erik Andersen, Arkæologiska skrifter 14, edited by Morten Ravn, Lone Gebauer Thomsen, Eva Andersson Strand and Henriette Lyngstrøm, pp. 119-36. Saxo-Instituttet Københavns Universitet, København.

Kahl, H. and Bendix A. Horn

1998 Vikinger på Nordatlanten. Skoletjenesten. Vikingeskibshallen, Roskilde.

Larson, Laurence Marcellus (translator)

1917 The King's Mirror [http://www.gutenberg.org/files/61264/61264-h/61264-h.htm\#Page_81] last accessed 03.07.2020.

Mannering, Ulla, Margarita Gleba and Marianne Bloch Hansen

2012 Denmark, In Textile and Textile Production in Europe, From prehistory to AD 400, Ancient Textile Series Volume 11, edited by Margarita Gleba and Ulla Mannering, pp. 91-118. Oxbow books. Oxford.

Mannering, Ulla

2016 Iconic Costumes: Scandinavian Late Iron Age Costume Iconography. Ancient Textiles Series Volume 25, Oxbow Books. Oxford.

2017 Forhistorisk dragt. In Arkceologisk tekstilforskning, bakgrund og ny viden, edited by Ulla Mannering, pp. 5-43. National Museum of Denmark, København.

Möller-Wiering, Susan

2002 Segeltuch und Embellage: Textilien im mittelalterlichen Warentransport auf Nord- und Ostsee, Internationale Archeaologie 70. Verlag Marie Leidorf GmbH, Rahden.

Nørgård, Anna

2016 Store og små sejl - tidsforbrug ved spinding og vævning. In Vikingetidens sejl, festskrift tilegnet Erik Andersen, Arkæologiska skrifter 14, edited by Morten Ravn, Lone Gebauer Thomsen, Eva Andersson Strand and Henriette Lyngstrøm, pp. 77-96. Saxo-instituttet, Københavns Universitet, København.

Sarauw, Torben

2019 Bejsebakken: en nordjysk bebyggelse fra yngre jernalder og vikingetid. Det Kongelige Nordiske Oldskriftselskab, Syddansk Universitetsforlag, København.

Sindbæk, M. Søren

2011 Silver Economies and Social Ties: Long-Distance Interaction, Long-term Investments - and why the Viking Age happened. In Silver Economies, Monetisation and Society in Scandinavia, AD 800-1100, edited by James Graham-Campbell, Søren M. Sindbæk and Gareth Williams, pp. 41-66. Aarhus University Press, Aarhus.

Skals, Irene, Ulla Mannering and Eva Andersson Strand

forthcoming Wool quality in Danish prehistoric textiles. 3000 years of sheep wool production 
Skoglund, Göran, Margareta M. Nockert and Bodil Holst

2013 Viking and early Middle Ages northern Scandinavian textiles proven to be made with hemp. Nature: Scientific reports, vol. 3, no. 2686: 1-6.

Skre, Dagfinn

2011 Commodity money, silver and coinage in Viking-Age Scandinavia. In Silver Economies,

Monetisation and Society in Scandinavia, AD 800-1100, edited by James Graham-Campbell,

Søren M. Sindbæk and Gareth Williams, pp. 67-91. Aarhus University Press, Aarhus.

Sørensen, Anne C

2001 Ladby, A Danish Ship-Grave from the Viking Age, Ships and Boats of The North, Vol. 3. Viking Ship Museum in collaboration with the National Museum of Denmark and Kertemindeegnens Museer, Roskilde.

Traetteberg, Gunvor Ingstad

1999 Skinnhyre og sjøklaer: Fiskerbondens utrustning på 1700- og 1800- tallet. Landbruksforlaget, Oslo.

Porláksson, Helgi

1991 Vaðmál og verðlag. Vaðmál i utanlandsviðskiptun og í búskap, Íslendinga á 13. og 14. Háskóla Íslands, Reykjavik.

Vedeler, Marianne

2019 The Oseberg Tapestries. Scandinavian Academic Press, Oslo.

Øye, Ingvild

2016 Tools and Textile Production in the North Atlantic. In Shetland and the Viking World: Papers from the seventeenth Viking Congress, edited by Val E. Turner, Olwyn A. Owen and Doreen J. Waugh. Shetland Heritage Publications, Lerwick.

\section{Oral Communication}

Ida Demant, Lejre Land of Legends, Roskilde, Denmark. Anna Nørgård, Vikingship museum, Roskilde, Denmark.

Morten Fischer Mortensen \& Lisbeth Prøsch-Danielsen, The National Museum of Denmark: Hemp and Heathens - Large scale hemp production during the Viking and Middles Ages in Denmark presentation at the Borgring conference November 2018, University of Copenhagen. [https://saxo.ku.dk/forskning/seed-money-saxo/vikingetid/borgring_conference_2018_programme.pdf] 